\title{
Rules of Engagement: Factors Influencing Employees Engagement in Insurance Companies
}

\author{
Medina Halako Twalib \\ School of Business, University of Nairobi, Nairobi, Kenya \\ Email address: \\ halaquo@uonbi.ac.ke \\ To cite this article: \\ Medina Halako Twalib. Rules of Engagement: Factors Influencing Employees Engagement in Insurance Companies. Journal of Human \\ Resource Management. Vol. 9, No. 3, 2021, pp. 69-76. doi: 10.11648/j.jhrm.20210903.13
}

Received: July 12, 2021; Accepted: July 29, 2021; Published: August 9, 2021

\begin{abstract}
Organizations are striving to find better ways of engaging their employees since many organizations have realised that workers are the most imperative resource for achieving their goals. Several research studies have been published that identify factors that drive employee engagement. Opportunities for upward feedback, effective communication systems, trust and fairness are some of the factors found to determine employee engagement. This study appreciates that a 'one size fits' model is effective, since the levels of engagement and its drivers differ according to organization, employees and the job itself. However, these studies had some inefficiencies including contextual and methodological deficiencies that the current study is addressing. The objective of the study was to establish factors that affect employee engagement at jubilee insurance. The study employed Cross Sectional Descriptive survey research design because the study was done at one point in time. Questionnaires were distributed to 175 respondents out of a population of 580. The study employed Factor analysis as a tool for data analysis. Results showed that four factors influence employee engagement. Management should ensure that they provide the necessary environment for employees to improve their performance in terms of increasing their employees' skills through training and development human resource practices. The study recommends that managers ensure they have a good relationship with employee and promote teamwork in the organization as well as give prompt performance feedback to employees.
\end{abstract}

Keywords: Employee Engagement, Performance, Teamwork, Nature of Job, Development Dimensions International (DDI)

\section{Introduction}

Employee engagement is an inner state of being that gathers earlier models of work effort, organizational commitment, work satisfaction and optimal experience [2]. Engagement is a fulfilling, work related experience characterized by dynamism, devotion and captivation [7]. By implication, employee engagement encourages human resource practitioners to define terms withing their scope of work so that results might be more readily measured hence more meaningful [10]. According to [8], engaged personnel are those that work with dedication and who feel connected to their organization. Alfes posited that engaged workers are more productive, more innovative and are likely to be retained with the employer, are healthier and enjoy their work more than others [1]. Employee engagement focus in bringing out an intrinsic desire to work for the company. [3] argues that employee involvement is demonstrated in employees' positive attitudes and behaviour and indication of trust, equity and a commitment are fulfilled.

The Gallup Organization noted that there are three types of employees; engaged employees [8]. They consistently endeavour to give quality within their roles. They are devoted toothier role, unlikely to quit, more industrious, hence brings in greater profits in organization. The second category according to [8] is the not engaged personnel. They emphasis on the tasks spelt rather than the goals of the organization. They do what is in their job description are "checked out" and "sleepwalking" through their day with less interest, or any personal investment. They are usually neither positive nor negative about their company. The third types are the actively disengaged employees. Gallup noted that these are employees who not only don't do well, but demotivate others as well [8]. They are always complaining and criticizing and undermining colleagues' efforts to promote a negative attitude and environment. Engaged employees enhances a healthy organization because employees are satisfied, committed, innovative and highly performing, with optimal 
physical, mental health. It is possible to achieve an engaged workforce with a true effort from the management by facilitating them with right opportunities [15].

\section{Literature Review}

There is a lot of literature on factors that drive employee engagement. A study done by [11] reviewed how organizations have taken the concept of employee engagement, it's measurements and benefits that are allied with increased engagement. The study highlighted the opportunities arising in undertaking a person-centered method of engagement and introduced a model of "positive engagement" that draws on the parallels between the constructs of engagement and happiness and considered the drivers that could facilitate increased levels of engagement and opportunities that exist in converging on factors that are internal to the employee, such as annotations and attitude. A study done by [5] on what drives employee engagement, found that employee engagement is driven by opportunities for upward feedback, effective consultation and communication systems and a manager who is fair and visibly committed to the organization. He noted that it is unlikely that a 'one size fits' approach is effective, as the levels of engagement and its drivers vary according to the organization, employee group, the individual and the job itself. [4] did a study on establishing the psychological conditions that influence employee to either engage or disengage themselves in their work. The study found out that the presence of three psychological conditions including meaningfulness, safety and availability were the major influences.

A study done by [12] found a moderate positive relationship between transformation leadership and employee engagement, moderate positive relationship between transactional leadership and employee engagement and low negative correlation between passive-avoidant Leadership and employee engagement. The study also found a nonsignificant correlation between age, education and employee engagement [12].

A conference board embarked on a study of determining the factors that lead to employees' engagement and the results indicated that the most commonly factors include trust and integrity, the nature of the job, the line of sight between employee and organization performance, career growth opportunities, organization identification with the company, relationships with colleagues, employee development and personal relationship with one's manager. The factors discussed in the paper consist of key drivers given from a combination of both the conference board [9] (2006) and DDI (2007). These factors include; nature of the job, individual performance and the company performance, development opportunities, pride about the company, recognition and reward, quality communications, team members, Personal relationship with one's manager and inspiring leadership.

The study was underpinned to the three-component model of engagement which was advanced by [7]. They posited that work is a pleasing state of the mind characterized by vigour, dedication and absorption. They posited that engaged employees take greater initiative and generate their own positive feedback. They found a positive correlation on three job resources (performance feedback, social support and supervisory coaching and work engagement (vigour, dedication and absorption) in four varied samples of Dutch employees. Structural equation model was used and the results indicated that job resources exclusively predicted engagement and that engagement was proved to be an intervener of the relationship between job resources and turnover intentions. [7] developed a tool for measuring work engagement and the concepts to be measured included vigour, dedication and absorption. They established the Utreched Work Engagement Scale (UWES) and tested the correlation between employee engagement and job performance on Dutch employees. A study done by [6] on burnout and engagement in university students from Spain used confirmatory factor analysis showed that the expected three factor structures of the adapted version fitted to the data of each sample. The results indicated invariance of factor loadings of Absorption in all samples and of vigor in two of the three samples.

Equal opportunity, fair treatment and communication had higher indices on a research done by [13] on the endorsement of employee engagement through human capital. These employee engagement factors will also be considered and tested in this study. According to [14], factors influencing employee engagement include recruitment, job design, career development opportunity, leadership, empowerment, equal opportunities and fair treatment, training and development, performance management, compensation, health and safety, job satisfaction, communication and family friendliness. Some of these factors will be considered in this current study.

The study is also underpinned to the self-Determination Theory (SDT) which is a need fulfilment-based model of motivation that can provide a theoretical model for employee engagement. The fulfilment of the three main psychological needs; autonomy, competence and relatedness at the place of work may be the cause of increased levels of employee engagement as postulated by self-Determination Theory.

\section{Research Methodology}

The study used census survey where all members of the population were included. The population comprised all the managers, employees and supervisors in various branches of the insurance company which is a total number of five hundred and eighty employees in the stations. The study used a sample size of 175 respondents. Stratified random sampling was used to get the number of respondents from the different cadres of the organization. Table 1 below shows the sampling frame from the different divisions of the organization. 
Table 1. A Table showing Population and Sample Distribution of the Respondents.

\begin{tabular}{lll}
\hline Division & Population & Sampling Size \\
\hline Human Resources & 110 & 30 \\
Finance & 15 & 14 \\
Operations & 150 & 42 \\
Business Development & 100 & 28 \\
Corporate Planning & 30 & 9 \\
Procurement & 50 & 16 \\
Technical Services & 90 & 26 \\
& 580 & 175 \\
\hline
\end{tabular}

Source: Author, 2017

Primary data was collected through structured questionnaires comprising of both open and closed ended questions. Questionnaires were preferred in this study because of the large number of respondents involved. The questionnaire comprised of two sections; where section one covered the biodata information of the respondents, section two covered questions on the level of employee engagement. The questionnaires will be administered through drop and pick later method. Data was analysed using both descriptive and inferential methods of data analysis. Factor analysis was used to determine the factors that affect employee engagement at jubilee insurance company.

\section{Data Analysis}

Preliminary data was analysed using descriptive statistics; mean, standard deviation and coefficient of variation were used.

Table 2. Table showing Gender Distribution.

\begin{tabular}{lll}
\hline Gender & Frequency & Percentage \\
\hline Male & 96 & 54.86 \\
Female & 79 & 45.14 \\
Total & 175 & 100 \\
\hline
\end{tabular}

Table 2 above showed the results for the gender distribution of the company. Male respondents had a $54.86 \%$ distribution while female employees (79) had a percentage of $45.14 \%$. This indicated that there were more male respondents in the company than there was female.

Table 3. Table showing the Departments of the Respondents.

\begin{tabular}{lll}
\hline Department & Frequency & Percentage \\
\hline Human Resource Department & 30 & 17.1 \\
Operations & 42 & 24 \\
Business Development & 28 & 16 \\
Finance & 14 & 8 \\
Technical Services & 36 & 20.57 \\
Procurement Department & 16 & 9.14 \\
Corporate Planning & 9 & 5.14 \\
Total & 175 & 100 \\
\hline
\end{tabular}

The results shown in table 3 above indicates that the department with the highest respondents in the study are from the operations department with a percentage distribution of $24 \%$, followed by technical services with a percentage distribution of $20.57 \%$, Human resource department $17.1 \%$, Business development department with 16\%, Procurement department 9.14\%, Finance department 5.8\% and Corporate Planning with a percentage distribution of $5.14 \%$.

Table 4. A Table showing Age Distribution of the Respondents.

\begin{tabular}{lll}
\hline Age & Frequency & Percentage \\
\hline $24-29$ & 10 & 5.74 \\
$30-35$ & 44 & 25.14 \\
$36-41$ & 69 & 39.43 \\
$42-47$ & 31 & 17.71 \\
$48-53$ & 19 & 10.86 \\
Over 53 & 2 & 1.14 \\
Total & 175 & 100 \\
\hline
\end{tabular}

Table 4 indicated the respondents' age and majority of them lies between the age of 36-40, followed by age 30-35 and the least number of respondents were aged over 53 years of age.

Table 5. A Table showing the results for Length of Service.

\begin{tabular}{lll}
\hline Length of Service & Frequency & Percentage \\
\hline $0-5$ & 52 & 29.71 \\
$6-10$ & 67 & 38.29 \\
$11-15$ & 54 & 30.86 \\
$16-20$ & 2 & 1.14 \\
Total & 175 & 100 \\
\hline
\end{tabular}

Majority of the respondents have worked for company for between 6-10 years, followed by 11-15 years. This indicates that employee at the organization stay for long periods working for the organization.

Table 6. A Table showing the results for Academic Qualifications of the Respondents.

\begin{tabular}{lll}
\hline Academic Qualifications & Frequency & Percentage \\
\hline A level & 15 & 8.57 \\
Diploma & 69 & 39.43 \\
Degree & 65 & 37.14 \\
Master Degree & 26 & 14.86 \\
Total & 175 & 100 \\
\hline
\end{tabular}

Results in table 6 above indicated that employees with A level qualification were 15 , those with diploma certificates were 69 , degree holders were 65 and those with master degree were 26. This shows that the employees in the organization are literate and can make informed decisions.

Table 7. A Table showing Mean, Standard Deviation and Coefficients of Variation of the Data Collected.

\begin{tabular}{lllll}
\hline Statements & N & Mean & Std. Deviation & Coefficient of Variation \\
\hline I understand what the management tells me & 175 & 3.41 & 0.49 & 0.14 \\
I am free to give comments and opinions & 175 & 3.61 & 0.65 & 0.18 \\
My suggestions are taken seriously & 175 & 3.57 & 0.57 & 0.16 \\
My supervisor cares about me as a person & 175 & 3.57 & 0.50 & 0.14 \\
I approach my supervisor with my problems & 175 & 3.25 & 0.43 & 0.13 \\
My immediate supervisor treats me impartially & 175 & 3.22 & 0.42 \\
\hline
\end{tabular}




\begin{tabular}{lllll}
\hline Statements & N & Mean & Std. Deviation & Coefficient of Variation \\
\hline My supervisor handles my work-related concerns satisfactorily & 175 & 3.14 & 0.35 & 0.11 \\
I know what is anticipated of my job & 175 & 3.43 & 0.50 & 0.14 \\
Workload is equally distributed throughout our company & 175 & 3.48 & 0.50 & 0.14 \\
I feel competent and able to grip my job & 175 & 3.47 & 0.50 & 0.14 \\
I have established career path & 175 & 3.38 & 0.49 & 0.14 \\
Promotions are handled fairly in my organization & 175 & 1.53 & 0.50 & 0.33 \\
I know the promotion opportunities in jubilee insurance & 175 & 1.52 & 0.50 & 0.33 \\
There is a good communication between my supervisor and myself & 175 & 1.51 & 0.50 & 0.33 \\
Management pays attention to all its employees at all levels & 175 & 2.74 & 0.44 & 0.16 \\
The company provides the relevant equipment's to do my job effectively & 175 & 2.65 & 0.48 & 0.18 \\
I have assurance in the leadership of Jubilee Insurance & 175 & 2.71 & 0.46 & 0.17 \\
I have an opportunity to learn and grow in jubilee & 175 & 4.15 & 0.42 & 0.1 \\
Management exercises fair and honesty in all judgements & 175 & 4.20 & 0.64 & 0.15 \\
I clearly understand my company goals & 175 & 4.09 & 0.68 & 0.17 \\
My individual goals are connected directly to the company's goals & 175 & 1.37 & 0.48 & 0.35 \\
My job contributes to the organizational performance & 175 & 1.40 & 0.51 & 0.37 \\
I am rewarded whenever I achieve my targets & 175 & 1.45 & 0.50 & 0.34 \\
The benefits offered to me are sufficient & 175 & 3.72 & 0.63 & 0.17 \\
I am recognized and praised for a good job & 175 & 3.74 & 0.57 & 0.15 \\
I am proud to be identified with Jubilee Insurance & 175 & 3.66 & 0.50 & 0.14 \\
I can recommend customers and employees to this company & 175 & 3.74 & 0.44 & 0.12 \\
I wish to remain in this company & 175 & 3.42 & 0.50 & 0.14 \\
Teamwork is encouraged in this company & 175 & 3.43 & 0.50 & 0.14 \\
I share information and new ideas with my co-workers freely & 175 & 3.40 & 0.49 & 0.14 \\
There is great teamwork in this company & 175 & 3.37 & 0.48 & 0.14 \\
Total & & 3.07 & 0.50 & 0.16 \\
\hline
\end{tabular}

Table 7 above shows the results of the means, standard deviation and coefficient of variation of the statements that were responded to in the questionnaires. The statement with the highest mean is "Management exercise fairness and honesty in all judgements" with a mean of 4.20, standard deviation of 0.64 and a coefficient of variation of 0.15 . This indicates that majority of the respondents agree to a great extent that the management exercise fairness in their judgements. On the other hand, the statement with the lowest mean is "My individual goals are connected directly to the company's goals" with a mean score of 1.37 , standard deviation of 0.48 and a coefficient of variation of 0.35 . This indicates that majority of the respondents agree to a very less extent that their goals are connected directly to the company's goals. The average mean score is 3.07 with a standard deviation of 0.50 and a coefficient of variation of 0.16 . The overall mean score indicates that the respondents agreed to a moderate extent with the statements provided on the factors that affect employees' engagement.

The correlation coefficients matrix of the factors ranged from -0.01 to 0.5 . This indicated a low correlation between the factors. It therefore allows for using the orthogonal type of factor analysis since the factors are not highly correlated.

Table 8. Table of Diagnostic Tests.

\begin{tabular}{lll}
\hline KMO and Bartlett's Test & \\
\hline \multicolumn{3}{l}{ Kaiser-Meyer-Olkin Measure of Sampling Adequacy. } \\
\hline \multirow{3}{*}{ Bartlett's Test of Sphericity } & Approx. Chi-Square & $\mathbf{. 4 8 7}$ \\
& Df & 444.428 \\
& Sig. & .000 \\
\hline
\end{tabular}

Table 8 above shows the KMO measure of sampling adequacy as 0.487 which is considered adequate by experts as it has a significance level of less than 0.05. Bartlett's test of Sphericity had an approximated chi-square of 944.428 with a degree of freedom 465 .

Table 9. Showing the communalities and extractions of the variables.

\begin{tabular}{lll}
\hline Communalities & Initial & Extraction \\
\hline & 1.000 \\
\hline I can understand what the management tells me & 1.000 \\
I feel free to offer comments and suggestions & 1.000 \\
I feel actions are taken on my suggestions & 1.000 \\
My supervisor cares about me as a person & 1.000 \\
I can freely approach my supervisor with problems & 1.000 \\
My immediate supervisor treats me fairly & 1.000 \\
I know what is expected of my job & 1.000 \\
Workload is distributed equally throughout our department & 1.000 \\
My supervisor handles my work-related issue satisfactorily & 1.000 \\
I feel competent and fully able to handle my job & 1.000 \\
I have clearly established career path & 1.000 \\
Promotions are handled fairly in my organization & .588 \\
I am aware of the promotion opportunities in jubilee insurance & .622 \\
There is a good communication between staff and managers & .487 \\
\hline
\end{tabular}




\begin{tabular}{lll}
\hline Communalities & & Extraction \\
\hline & Initial & .738 \\
\hline Management care for all its employees at all levels & 1.000 & .578 \\
I have the materials and equipment I need to do my job effectively & 1.000 & .700 \\
I have confidence in the leadership of Jubilee Insurance & 1.000 & .600 \\
I have an opportunity to learn and grow & 1.000 & .691 \\
Management exercises fair and honesty in all judgments & 1.000 & .730 \\
I clearly understand my company goals & 1.000 & .634 \\
My individual goals are connected directly to the company's goals & 1.000 & .696 \\
I understand how my job contributes to the organizational performance & 1.000 & .766 \\
If I do good, I can be rewarded & 1.000 & .707 \\
I am happy with the benefits offered to me & 1.000 & .645 \\
I am recognized and praised for a good job & 1.000 & .619 \\
I am proud to be identified with Jubilee Insurance & 1.000 & .616 \\
I can recommend customers and employees to this company & 1.000 & .652 \\
I wish to remain in this company & 1.000 & .669 \\
I enjoy working with my co-workers & 1.000 & .770 \\
My co-workers and I share information and new ideas & 1.000 & .715 \\
The people I work with help each other when needed & 1.000 & \\
Extraction Method: Principal Component Analysis. & & \\
\hline
\end{tabular}

The results in table 10 above indicated the extraction coefficient of the factors using the principal component analysis method. The factor with the highest coefficient is "My co-workers and I share information and new ideas," (0.849) while the factor with the lowest coefficient is "I can freely approach my supervisor with problems", (0.487).

Table 10. Showing Results for Total Variance.

\begin{tabular}{|c|c|c|c|c|c|c|}
\hline \multicolumn{7}{|c|}{ Total Variance Explained } \\
\hline \multirow{2}{*}{ Component } & \multicolumn{3}{|c|}{ Initial Eigenvalues } & \multicolumn{3}{|c|}{ Extraction Sums of Squared Loadings } \\
\hline & Total & $\%$ of Variance & Cumulative \% & Total & $\%$ of Variance & Cumulative \% \\
\hline 1 & 2.560 & 8.257 & 8.257 & 2.560 & 8.257 & 8.257 \\
\hline 2 & 2.144 & 6.915 & 15.172 & 2.144 & 6.915 & 15.172 \\
\hline 3 & 2.016 & 6.503 & 21.674 & 2.016 & 6.503 & 21.674 \\
\hline 4 & 1.900 & 6.130 & 27.804 & 1.900 & 6.130 & 27.804 \\
\hline 5 & 1.639 & 5.287 & 33.092 & 1.639 & 5.287 & 33.092 \\
\hline 6 & 1.579 & 5.093 & 38.185 & 1.579 & 5.093 & 38.185 \\
\hline 7 & 1.564 & 5.046 & 43.231 & 1.564 & 5.046 & 43.231 \\
\hline 8 & 1.420 & 4.582 & 47.813 & 1.420 & 4.582 & 47.813 \\
\hline 9 & 1.291 & 4.163 & 51.976 & 1.291 & 4.163 & 51.976 \\
\hline 10 & 1.243 & 4.008 & 55.985 & 1.243 & 4.008 & 55.985 \\
\hline 11 & 1.192 & 3.844 & 59.828 & 1.192 & 3.844 & 59.828 \\
\hline 12 & 1.120 & 3.612 & 63.441 & 1.120 & 3.612 & 63.441 \\
\hline 13 & 1.006 & 3.245 & 66.685 & 1.006 & 3.245 & 66.685 \\
\hline 14 & .977 & 3.153 & 69.838 & & & \\
\hline 15 & .894 & 2.883 & 72.722 & & & \\
\hline 16 & .832 & 2.683 & 75.405 & & & \\
\hline 17 & .784 & 2.528 & 77.933 & & & \\
\hline 18 & .769 & 2.481 & 80.414 & & & \\
\hline 19 & .727 & 2.346 & 82.760 & & & \\
\hline 20 & .646 & 2.085 & 84.844 & & & \\
\hline 21 & .618 & 1.993 & 86.837 & & & \\
\hline 22 & .585 & 1.886 & 88.723 & & & \\
\hline 23 & .552 & 1.780 & 90.503 & & & \\
\hline 24 & .469 & 1.511 & 92.014 & & & \\
\hline 25 & .461 & 1.486 & 93.500 & & & \\
\hline 26 & .436 & 1.407 & 94.907 & & & \\
\hline 27 & .374 & 1.207 & 96.114 & & & \\
\hline 28 & .349 & 1.125 & 97.238 & & & \\
\hline 29 & .310 & .999 & 98.237 & & & \\
\hline 30 & .277 & .895 & 99.132 & & & \\
\hline 31 & .269 & .868 & 100.000 & & & \\
\hline \multicolumn{7}{|c|}{ Extraction Method: Principal Component Analysis. } \\
\hline
\end{tabular}

Table 10 above indicates the results for the variance of the factors arranged from the highest initial eigen values to the lowest initial eigen values with their percentage of variance and cumulative percentage of variance. Out of the thirty-one statements, the statements with eigen values of over 1 were extracted and they were thirteen. Their percentage of variance and cumulative percentage was also displayed in table 10. The last column shows the rotation of the sums of 
squared loadings and their percentage of variance and cumulative percentage. The statements which had less than one (1) eigen value were dropped hence not extracted and not rotated.

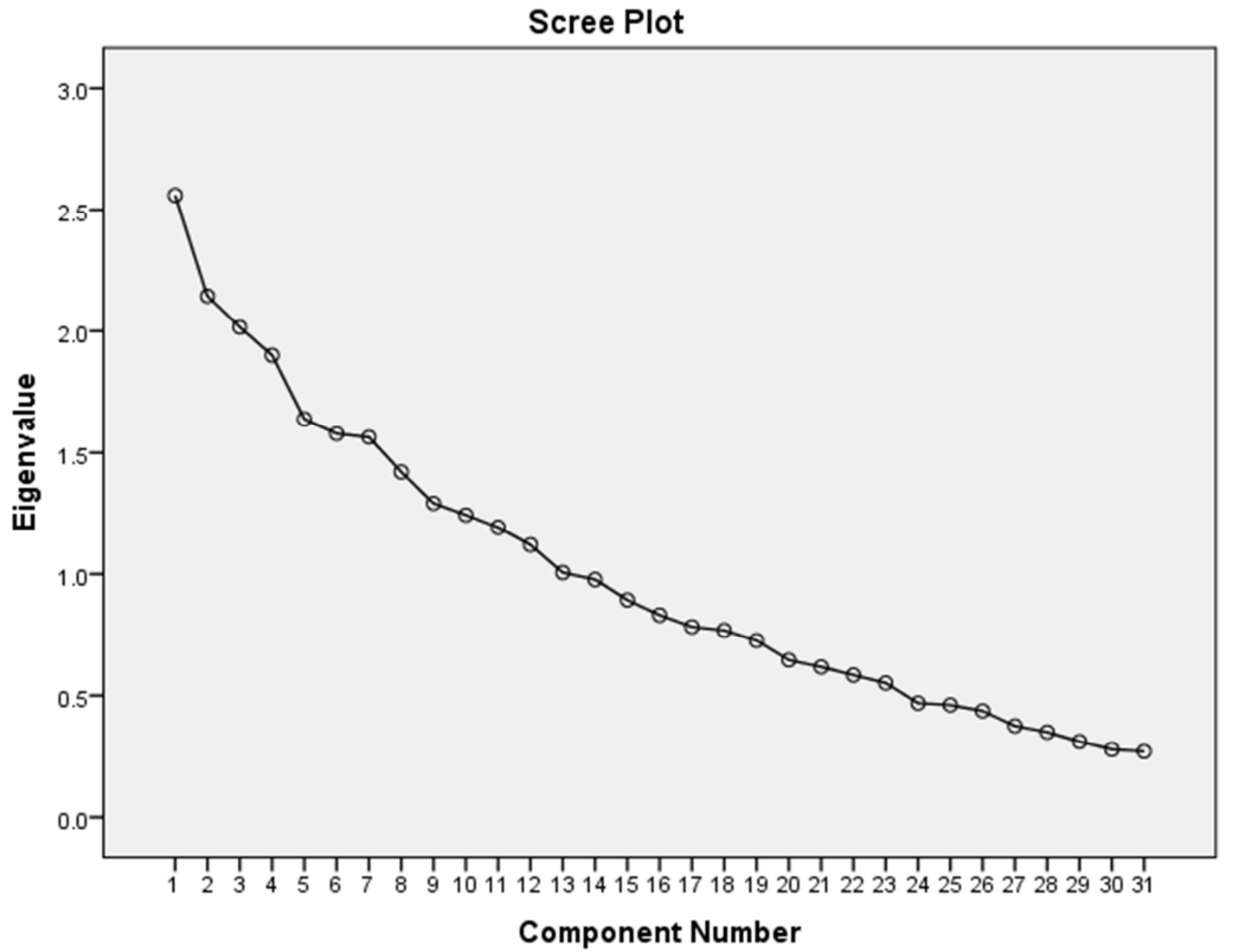

Figure 1. Scree Plot for the factors affecting Employee Engagement.

As shown in figure one above, the scree plot is showing the eigen values of the factors. After eigen value of one the scree plot starts flowing down as if it has similar points. Eigen value of one marks the cut off points for the factors to be extracted and rotated. It shows thirteen statements.

Table 11. Showing the Rotated Component Matrix of the factors affecting Employee Engagement.

\begin{tabular}{|c|c|c|c|c|c|c|c|c|c|c|c|c|c|}
\hline \multicolumn{14}{|l|}{ Component Matrix $^{a}$} \\
\hline & \multicolumn{13}{|c|}{ Component } \\
\hline & 1 & 2 & 3 & 4 & 5 & 6 & 7 & 8 & 9 & 10 & 11 & 12 & 13 \\
\hline I can understand what the management tells me & .364 & -.429 & .105 & -.182 & -.036 & .155 & -.045 & .151 & -.270 & -.217 & .131 & -.173 & .127 \\
\hline I feel free to offer comments and suggestions & .502 & -.082 & .125 & -.122 & .069 & -.357 & .046 & .242 & .037 & .222 & .111 & -.151 & .143 \\
\hline I feel actions are taken on my suggestions & -.076 & .100 & -.376 & .398 & .272 & -.171 & .120 & .067 & -.242 & -.291 & -.066 & -.033 & .183 \\
\hline My supervisor cares about me as a person & .636 & .304 & -.183 & .154 & .012 & .130 & .026 & .017 & -.065 & .094 & -.038 & .180 & -.052 \\
\hline I can freely approach my supervisor with problems & .349 & .341 & .273 & .055 & .196 & .026 & -.108 & .072 & -.050 & .110 & -.096 & .272 & -.133 \\
\hline My immediate supervisor treats me fairly & -.120 & -.152 & -.016 & .438 & -.254 & -.466 & .102 & .057 & -.154 & .079 & .227 & -.015 & -.081 \\
\hline I know what is expected of my job & -.156 & .525 & -.271 & -.119 & .315 & .132 & .290 & -.007 & .108 & .095 & -.009 & .019 & .239 \\
\hline Workload is distributed equally throughout our department & -.005 & .113 & .402 & .586 & .104 & .147 & .097 & -.020 & .167 & -.188 & -.059 & -.153 & .057 \\
\hline My supervisor handles my work related issue satisfactorily & .002 & -.119 & -.124 & .162 & .504 & .090 & -.161 & .226 & -.246 & .368 & -.089 & -.124 & .258 \\
\hline I feel competent and fully able to handle my job & -.212 & .148 & .226 & -.317 & .570 & .081 & .026 & -.017 & .092 & .202 & .206 & -.193 & -.199 \\
\hline I have clearly established career path & .342 & .284 & -.292 & .185 & .069 & .193 & .196 & -.328 & .096 & -.252 & .299 & .235 & -.166 \\
\hline Promotions are handled fairly in my organization & -.392 & .162 & .364 & -.163 & -.230 & .205 & .242 & .000 & .218 & -.299 & .213 & -.019 & .178 \\
\hline $\begin{array}{l}\text { I am aware of the promotion opportunities in jubilee } \\
\text { insurance }\end{array}$ & .391 & -.207 & -.100 & -.040 & -.278 & .177 & .378 & .343 & -.200 & .080 & .131 & .143 & .302 \\
\hline $\begin{array}{l}\text { There is a good communication between my supervisor and } \\
\text { myself }\end{array}$ & .594 & .035 & .026 & .157 & -.144 & .222 & -.200 & .078 & .322 & .222 & -.148 & .135 & -.068 \\
\hline Management care for all its employees at all levels & -.182 & -.364 & -.116 & -.123 & .161 & .402 & -.005 & .400 & .401 & .083 & .153 & .009 & -.075 \\
\hline $\begin{array}{l}\text { I have the materials and equipment I need to do my job } \\
\text { effectively }\end{array}$ & -.194 & .148 & -.490 & -.130 & -.318 & .087 & -.143 & .221 & .144 & -.099 & -.149 & .175 & -.025 \\
\hline I have confidence in the leadership of Jubilee Insurance & -.235 & .254 & -.164 & -.355 & -.089 & -.083 & .370 & .362 & .071 & -.006 & -.339 & .104 & .120 \\
\hline I have an opportunity to learn and grow & -.231 & -.085 & -.152 & .122 & .068 & -.132 & .131 & .191 & .077 & .324 & .471 & .284 & -.109 \\
\hline
\end{tabular}




\begin{tabular}{|c|c|c|c|c|c|c|c|c|c|c|c|c|c|}
\hline \multicolumn{14}{|l|}{ Component Matrix ${ }^{\mathrm{a}}$} \\
\hline & \multicolumn{13}{|c|}{ Component } \\
\hline & 1 & 2 & 3 & 4 & 5 & 6 & 7 & 8 & 9 & 10 & 11 & 12 & 13 \\
\hline Management exercises fair and honesty in all judgments & .157 & .239 & -.010 & .073 & .089 & -.050 & -.540 & .092 & .313 & -.164 & -.166 & -.042 & .372 \\
\hline I clearly understand my company goals & .036 & .065 & .380 & -.049 & .128 & -.474 & .268 & .090 & -.023 & -.029 & -.253 & .435 & -.048 \\
\hline $\begin{array}{l}\text { My individual goals are connected directly to the company's } \\
\text { goals }\end{array}$ & .007 & .181 & .469 & -.129 & .099 & .186 & -.150 & .016 & -.262 & -.174 & .258 & .226 & .284 \\
\hline $\begin{array}{l}\text { I understand how my job contributes to the organizational } \\
\text { performance }\end{array}$ & 163 & 406 & .027 & -.135 & -.177 & -.287 & -.027 & .212 & .056 & .001 & -.082 & -.474 & -.304 \\
\hline If I do good I can be rewarded & .043 & .122 & -.185 & -.187 & -.351 & -.102 & -.076 & -.455 & 183 & .430 & 198 & -.026 & 277 \\
\hline I am happy with the benefits offered to me & .042 & .446 & .203 & .168 & -.295 & .236 & .200 & -.149 & -.197 & .290 & .024 & -.289 & .155 \\
\hline I am recognized and praised for a good job & .355 & .412 & .171 & -.262 & .061 & -.183 & .267 & .213 & .104 & -.114 & .234 & -.139 & -.006 \\
\hline I am proud to be identified with Jubilee Insurance & -.534 & .159 & .194 & .064 & -.181 & .099 & -.015 & -.015 & -.227 & .302 & -.262 & .092 & .060 \\
\hline I can recommend customers and employees to this company & .150 & -.266 & .254 & -.305 & .190 & .089 & .193 & -.419 & -.006 & .145 & -.248 & .155 & -.052 \\
\hline I wish to remain in this company & .007 & -.041 & -.213 & .433 & .178 & .257 & .491 & -.031 & .074 & .076 & -.156 & -.190 & -.078 \\
\hline I enjoy working with my co-workers & .214 & -.448 & .323 & .084 & -.172 & .098 & .353 & .004 & .281 & .024 & -.240 & -.090 & .044 \\
\hline My co-workers and I share information and new ideas & -.258 & .176 & .427 & .491 & -.143 & .059 & -.170 & .325 & .177 & .157 & .114 & .141 & -.045 \\
\hline The people I work with help each other when needed & .032 & .195 & .028 & -.162 & -.205 & .464 & -.107 & .220 & -.453 & .012 & -.046 & -.001 & -.352 \\
\hline
\end{tabular}

Extraction Method: Principal Component Analysis.

a. 13 components extracted.

Table 11 above shows the results of the Rotated Component Matrix of the statements affecting Employee Engagement. The statements with coefficients of above 0.5 falling under one factor will be put together and taken as a factor affecting employee engagement. Four factors were therefore developed. Based on this study, the following factors are deemed to affect employee engagement: Relationship with manager, Nature of the job, Teamwork and Employee Performance.

\section{Discussion of Findings}

The primary objective of the study was to find out the factors that influence employee engagement. Descriptive statistics presented in this study indicated that there is a minimal difference between the genders, which means that the company recognizes the importance of both genders in the organization. Age distribution showed that majority of the respondents is at the age bracket of between 30-41 years $(64.57 \%)$. This is the age where majority of the employees are actively involved in developing the organization. In terms of length of service, majority of the respondents have worked for the organization between 6-10 years (38.29\%). This is an indication that employees in the organization stay for longer periods before quitting in the organisation.

Results of the factor analysis indicated that four factors affect employee engagement. Relationship with the manager is one of the factors that have been proved by this study to influence employee engagement. The statements that confirmed this factor has also been proved by descriptive statistics where "I feel free to offer comments and suggestions," My supervisor cares about me as a person had mean scores of 3.61 and 3.57 respectively. This is in tandem with a study done [3] where he found that employee engagement is manifested in positive attitudes and a positive exchange within a psychological contract where two way promises and commitment are fulfilled.

Nature of job is another factor that has been found by this study to influence employee engagement. This has been supported by descriptive statistics done earlier in this study where the statement "workload is distributed equally," and "I know what is expected of my job," had a mean score of 3.48 and 3.43 respectively. This is an indication that majority of the respondents agree largely that nature of job is a factor that influences employee engagement. This has been supported by a study done by [1] who found that employees perceive their workload to be more sustainable than others do.

Another factor that influences employee engagement found by this study is employee performance. Descriptive statistics that support this factor include the mean scores of the statements, "I feel competent and fully able to handle my job," and "My supervisors handle my work-related issues satisfactory," with mean scores of 3.47 and 3.14 respectively. A study done by [1] supports this study. They found that engaged employees work better and are more innovative and likely to stay in the company. Further, [8] noted that more productive and give better customer service.

Teamwork is also one of the factors that influence employee engagement found by this study. This has also been proved by descriptive statistics in that the statements "Workload is distributed equally throughout our department," and "My co-workers and I share information and ideas," with mean scores of 3.48 and 3.40 respectively.

\section{Summary, Conclusion and Recommendations}

In summary, the study found sufficient data from the respondents with majority of the employees aged between 30-41 years, majority of the employees have worked for the organization between 6-10 years and are of good academic qualifications. The study found out that relationship with managers, nature of the job, teamwork and employee performance are the factors that influence employee engagement in Jubilee insurance company.

In conclusion therefore, employers need to understand these four factors and make full use of them to ensure 
employees are engaged hence achieve their objective. Relationship with the manager is one of the factors found to boost employee's engagement and therefore managers fairness, commitment and treating employees with respect and dignity can be some of the practices that managers need to employ in order to increase their relationship with employees at the workplace. In terms of performance, organizations need to employee a 360-degree feedback system where employees receive feedback on their performance. This will encourage them to be better in their work as they will keep on improving on areas of weaknesses. The finding that teamwork is one of the factors that influence employee's engagement means that management should embark on team building and ensure team building activities in their organization. They need to focus on teamwork and probably reward team effort more than individual effort in order to ensure employees engagement. The study finding that nature of job is one of the key factors that promotes employee engagement means that managers need to practice fairness and equity in terms of work distribution to employees. Managers need to plan work so that employees know what is expected of them at any one point.

The study recommends that employers should encourage teamwork in their organizations; they should ensure that the managers and lower employees have a good relationship. They should develop a policy that ensures employees are given the necessary tools in order to improve their performance which will then ensure that employees feel engaged in the organization. This way organization will benefit from the diverse ideas that will come from their employees for the development of the organization.

\section{References}

[1] Alfes, K., Truss, C., Soanne, E. C., Rees, C. and Gatenby, M. (2010). Creating and Engaged Workforce. London: Chartered Institute of Personnel and Development.

[2] Armstrong, M. (2006). Evidence-Based Reward Management. London, Kogan Page.

[3] Guest, D. (2009). Review of Employee Engagement. Notes for a Discussion (Unpublished). Prepared specifically for the MacLeod and Clarke (2009). Review of Employee Engagement.
[4] Kahn, W. (1990). Psychological Conditions of Personal Engagement and Disengagement at Work. Academy of Management Journal, 33 pp 692-724.

[5] Robinson, D. (2007). Staff Engagement is Marriage of Various Factors at Work. Employee Benefits, 3, pp 45-62.

[6] Schaufeli W. B., Martinez, I. S., Marques, P., Salanova, M., Baker, B. A. (2002). Burnout and Engagement in University Students. Journal of Cross-Cultural Psychology, 3, pp 71-92.

[7] Schaufeli, W. B. and Baker, A. B. (2006). "Same, Same" but Different? Can Work Engagement be Discriminated from Job Involvement and Organization Commitment? European Psychologist. Vol. 11 Issue 2 pp 119-127.

[8] The Gallup Organization (2010). What your Dissatisfied Workers Cost. Gallup Management Journal. Retrieved from Google http://gmj.gallup.com/content/default.aspx?ci=439.

[9] Gibbons, J., \& Conference Board (2006). Employee Engagement: A Review of Current Research and its Implications. New York: Conference Board.

[10] Endress, G. M. (2008). The Human Resource Craze: Human Performance Improvement and Employee Engagement. Organizational Development Journal; Chesterland, Vol. 26 Issue 1 pp 69-78.

[11] Stairs, M., \& Galpin, M. (2010). Positive Engagement: From Employee Engagement to Workplace Happiness. In P. A. Linley, S. Harrington, \& N. Garcea (Eds.), Oxford handbook of positive psychology and work (pp. 155-172). Oxford University Press.

[12] Popli, S. and Rizvi, I. A. (2016). Drivers of Employee Engagement: The Role of Leadership Style. Global Business Review, 17 (4): 965-979.

[13] Febriansyah, H. (2010). Endorsing Employee Engagement through Human Capital Approach; An Empirical Research. Social Responsibility, Professional Ethics and Management Proceedings of the $11^{\text {th }}$ International Conference, Ankara, Turkey, 24-27 November 2010.

[14] Sundaray, B. K. (2011). Employee Engagement: A Driver of Organizational Effectiveness. European Journal of Business and Management, Vol 3, Issue No. 8 ppl-8.

[15] Bhuvanaiah, T., Raya, R. P. (2015). Mechanism of Improved Performance: Intrinsic Motivation and Employee Engagement. SCMS Journal of Indian Management, a Quarterly Journal, pp92-97. 